\title{
PARASITIC NEMATODES IN POTATOES OF DIFFERENT VARIETIES AND THEIR INTERRELATIONS WITH SOME ARTHROPODS
}

\author{
Maria MELNIC1, Olesea GLIGA1, Dumitru ERHAN¹, Stefan RUSU1, Elena IORDOSOPOL ${ }^{2}$ \\ 1Institute of Zoology, MECR, Chisinau, Republic of Moldova \\ 2Institute of Genetics Physiology and Plants Protection, MECR, Chisinau, Republic of Moldova
}

Corresponding author: Olesea Gliga, e-mail: oleseagliga@gmail.com

DOI: $10.38045 /$ ohrm.2021.3.06

CZU: 633.491:576.895

Keywords: potato, Introduction. Potato (Solanum tuberosum L.) is susceptible to infestation with an associnematodes, arthro- ated complex of different species of parasitic and saprophytic nematodes, bacteria, fungi, pods, nematopha- and arthropods, which diminish the quality of the product.

gous, phytophagous.

Cuvinte cheie: cartof, nematode, artropode, nematofage, fitofage.
Material and methods. 10 varieties of potatoes were investigated (Agata, Albastriu-mov, Bella rosa, Concorde, Desiree, Irga, Iagodca, Roko, Romano, Sprinter), cultivated on the territory of the Republic of Moldova. The extraction of nematodes and mites was performed using the Baermann funnels, modified by Nesterov.

Results. Multiannual researches on the degree of potato infestation have shown that tubers are preferred by various arthropods (Acaridae), Agriothes spp. (Elateridae), Gryllotalpa gryllotalpa, (Grillotalpidae) and Sciaridae spp. (Sciaridae), which form different interactions with the parasitic nematodes of tubers (Ditylenchus destructor, D. dipsaci).

Conclusions. Solanum tuberosum infested by parasitic nematodes D. destructor in association with saprophytic nematodes and dry rot are colonized by nematophagous (mites - 80\%) and phytophagous arthropods (wireworms - 40\%; mole cricket - 50\%; flies - 40\%). Among the researched arthropods, Rhizoglyphus echinopus were more frequently found, which together with other species actively consume the primary and secondary parasitic nematodes, their mortality constituting up to 90\%. In the traumatized by some arthropods potatoes, with the soil, secondary parasitic nematodes, also penetrate, carrying bacterial and fungal infections, subsequently stimulating the total rot of potato tubers.

\section{NEMATODELE PARAZITE LA CARTOFII DE DIFERITE SOIURI ȘI INTERRELAȚIILE CU UNELE ARTROPODE}

Introducere. Cartoful (Solanum tuberosum L) este susceptibil la infestare cu un complex asociat de diferite specii de nematode parazite, saprofite, bacterii, ciuperci și artropode, ceea ce îi diminuează din calitatea lui ca produs.

Material și metode. Au fost cercetate 10 soiuri de cartofi (Agata, Albăstriu-mov, Bella rosa, Concorde, Desiree, Irga, Iagodka, Rocko, Romano, Sprinter) cultivate în Republica Moldova. Extragerea nematodelor și a acarienilor s-a efectuat cu utilizarea pâlniilor Baermann, modificate de Nesterov.

Rezultate. Cercetările multianuale, privind gradul de infestare a cartofilor, au demonstrat că tuberculii sunt preferați de diferite artropode: Agriotes spp. (Elateridae), Gryllotalpa gryllotalpa, (Grillotalpidae) și Sciaridae spp. (Sciaridae), care stabilesc interrelații diverse cu nematodele parazite (Ditylenchus destructor, D. dipsaci) ale culturii.

Concluzii. Solanum tuberosum, infestat de nematodul parazit Ditylenchus destructor, în asociere cu nematodele saprofite și cu putregaiul uscat, este colonizat de artropodele nematofage (acarieni - 80\%) și fitofage (viermii-sârmă - 40\%; coropișnițe - 50\%; musculițe 40\%). Printre artropodele cercetate, mai frecvent a fost atestat Rhizoglyphus echinopus (Fumouze \& Robin, 1868), care, împreună cu alte specii, consumă activ nematodele parazite primare și pe cele secundare, mortalitatea acestora constituind până la 90\%. În cartofii traumați de unele artropode, odată cu solul, pătrund și nematodele parazite secundare, purtătoare ale infecțiilor bacteriene și fungice, stimulând ulterior putrefacția totală a tuberculilor. 


\section{INTRODUCTION}

Potato (Solanum tuberosum L.) is the third most important food crop plant of the world, producing high yields of nutritionally valuable food in the form of tubers, which has captured the attention of many researchers. Because the tubers are susceptible to infestation with an associated complex of different species of parasitic and saprophytic nematodes, bacteria, fungi, and arthropods, it is important to know their impact on the host organism. Primary parasitic nematode Ditylenchus destructor (Thorne, 1945) creates pathways in tubers for secondary parasitic invertebrates such as: saprophytic nematodes, bacterial and fungal infections, these being vectors of infections for susceptible potato varieties. As a result, the resistance of potato crop is diminished and their complete putrefaction occurs (1).

The nematode $D$. destructor is widespread in all countries where potatoes are growing. For example, in Romania, in the process of studying the level of infestation with the nematode $D$. destructor and other pathogens, which cause diseases of the seed potato of 4 varieties - Desiree, Ostara, Dahlia, Alka, it has been established that the most susceptible to both the $D$. destructor and the pathogenic species of microorganisms are the varieties Desiree and Ostara (2). The frequency of the attack with $D$. destructor was $44.8 \%$ and $27.38 \%$, respectively, and the Dahlia and Alka varieties were more resistant, the frequency of the attack constituted $5.26 \%$ and $4.10 \%$, respectively. In the Republic of Belarus, in all agro-climatic zones, there have been cases of crop loss of up to $43 \%$, due to infestation with the $D$. destructor nematode of food and seed potatoes (3).

In phases 1, 2 of ditylenchosis the primary monotypic population of tubers is infested only with the population of a single species of nematode D. destructor (females, males, larvae of different ages) (4). In such tubers, parasitic nematodes do not cause obvious external symptoms of ditylenchosis and only by removing the shell, small stains on the surface of the tuber pulp appear low visible. In phases 4-5 of ditylenchosis, the tissue invaded by different secondary invertebrate organisms becomes evidently rotten (5). Ditylenchosis disease of tubers initially manifests by cracking the shell, similar to dry rot, caused by Fusarium spp.

The purpose of the research was the study of the species of nematophagous and phytophagous arthropods, as well as the complex of infections associated with potato tubers of 10 varieties, during the autumn-winter-spring periods.

\section{MATERIAL AND METHODS}

The researches were carried out during 20142019 years. The research was conducted on 10 varieties of potatoes (Agata, Albastriu-mov, Bella rosa, Concorde, Desiree, Irga, Iagodca, Roko, Romano, Sprinter), which were cultivated in the north, south and central areas of the Republic of Moldova. For each variety, 15-20 potatoes tubers per sample were researched. The primary and secondary parasites of tubers have been determined in advanced phases of ditylenchosis. The extraction of nematodes and mites was performed using the Baermann funnels, modified by Nesterov (6). The density of nematodes extracted from the tubers affected by ditylenchosis was calculated by applying the De Grisse chamber. The fixed preparations were carried out according to the method proposed by Seinhorst (7). The stereoscopic microscope was used to establish morpho-physiological changes in the infested potatoes.

Statistical analysis was performed using MS Excel program.

\section{RESULTS}

\section{Nematodes associated with rot}

It was determined that all the potatoes varieties collected during the autumn-winter-spring periods were infested with parasitic nematodes Ditylenchus destructor (advanced phases of ditylenchosis, 4-5) in combination with D. dipsaci, saprophytic nematodes, bacteria and fungi (fig. 1).

The results of the research showed a wide spread $(100 \%)$ of the obligate primary parasite $D$. destructor in all investigated 10 potato varieties. The varieties of Albastrui-mov, Dessiree and Irga differed in frequency and density of infestation. The most frequent (100\%) D. destructor is associated with dry rot caused by Fusarium spp. and less frequent (60\%) with wet rot caused by $\mathrm{Er}$ winia spp.

\section{Nematophagous arthropods - mites}

It was established that the studied potatoes tubers (Agata, Albastriu-mov, Bella rosa, Concorde, Desiree, Irga, Iagodca, Roko, Romano, Sprinter) infested with parasitic nematodes $D$. destructor, 


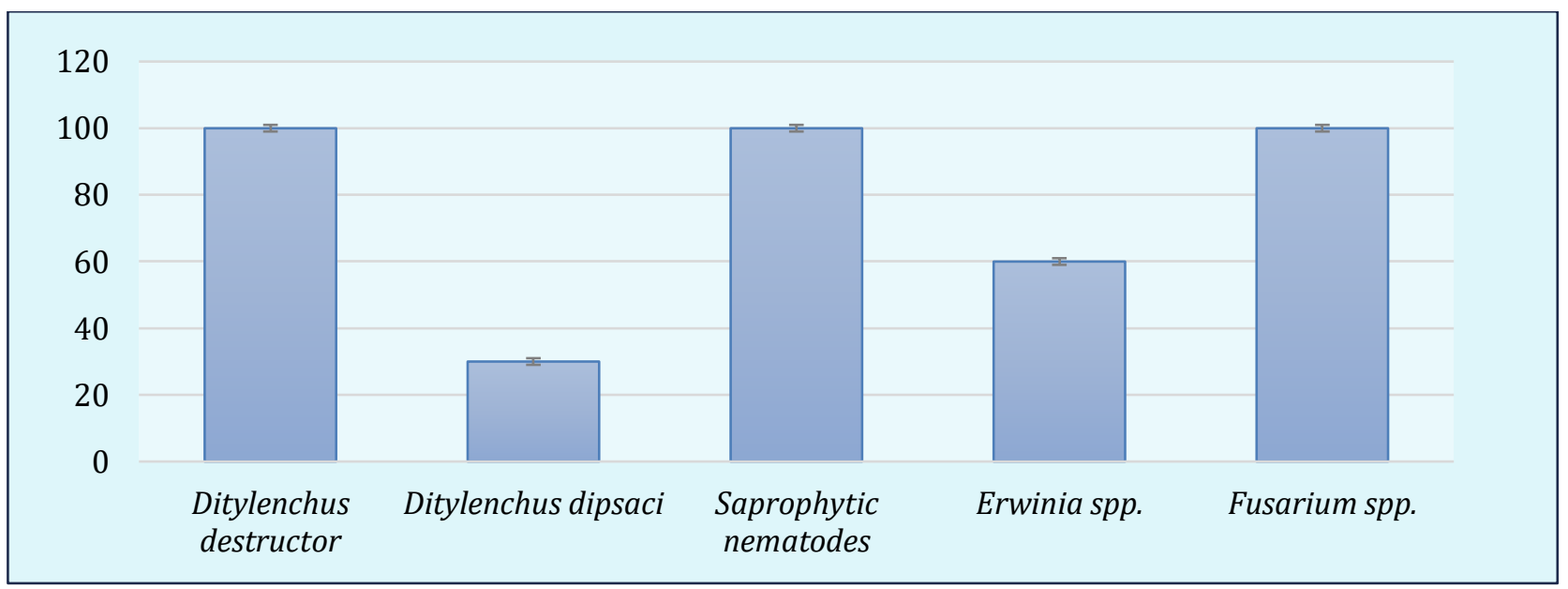

Figure 1. Frequency of parasitic and saprophytic nematodes, of dry and wet rot (\%) in the investigated potato varieties.

D. dipsaci, saprophytic nematodes, bacteria and fungi, were also colonized by different species of mites (fam. Acaridae), which have been commonly found in all the researched varieties (fig. 1, 2).

It should be mentioned the fact that the potato tu bers infested by $D$. destructor in association with saprophytic nematodes and dry rot were colonized by nematophagous (frequency $80 \%$, different species of mites) and phytophagous arthropods (wireworms - 40\%; mole cricket - 50\%; flies $-40 \%$ ) (fig. 2).

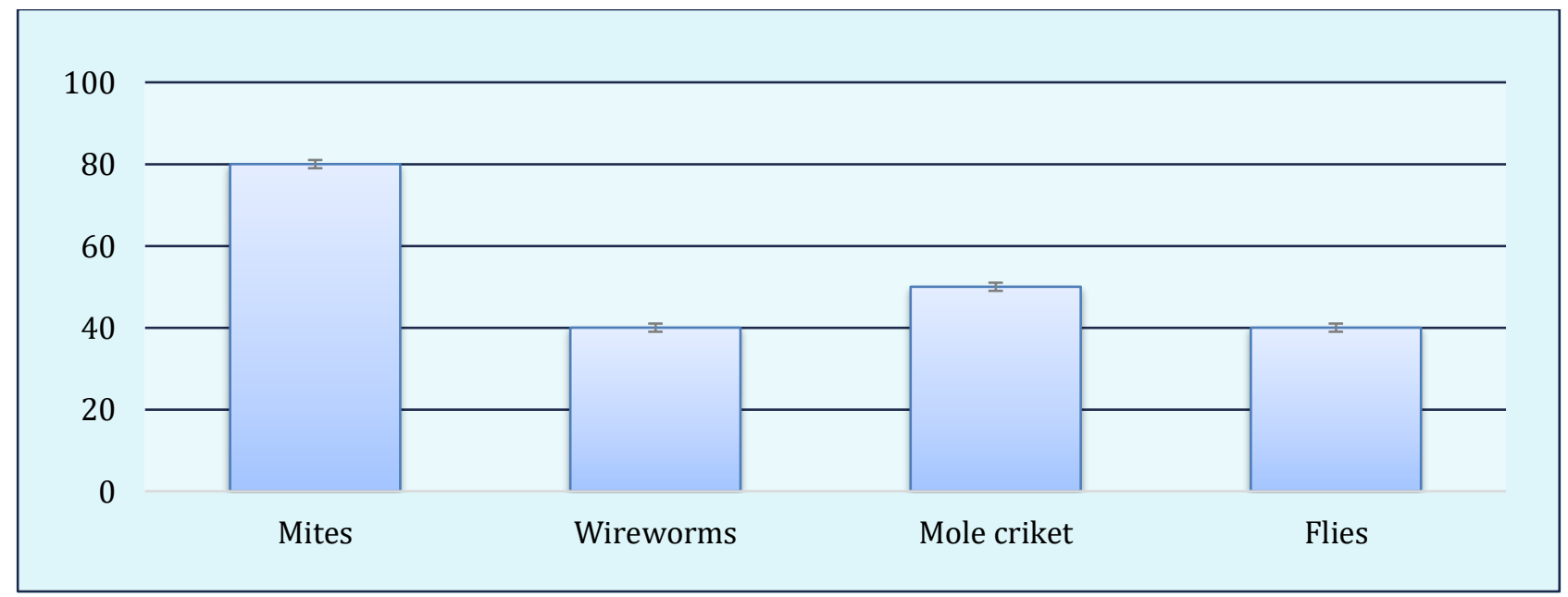

Figure 2. Frequency of nematophagous and phytophagous arthropods (\%) in the investigated potato varieties.

An increased density of mites (hundreds of individuals along with their eggs/potato tubers) was detected in 5 of the investigated varieties - Agata, Bella rosa, Desiree, Irga, Roko. In the study process, for the first time, cases of active mite's attack on primary (D. destructor, D. dipsaci) and secondary (facultative, most of them of the order Rhabditida) parasitic nematodes have been observed. The latter (females, males, larvae, eggs) are devoured and consumed by mites (fig. 3). Under such conditions, the mites lay eggs, from which the larval forms develop, which then leads to the post-embryonic development cycle.

All mite species present in potatoes tubers infested with nematodes and microorganisms proved to be active predators. It has been established that mites attack nematodes (from families: Anguinidae, Cephalobidae, Neodiplo-gasteridae, Rhabditidae etc.) usually, in the region of median intestine, along the reproductive tract (ovary, oviduct in this area the holes are obser- 
ved, through which the content of the organs is absorbed, first of all the gonad with the nematode eggs (fig. 4 (3a, 3b)). High mortality up to $90 \%$ both of primary and secondary parasitic nematodes has often been observed in such suspension (fig. 4 (1b)).

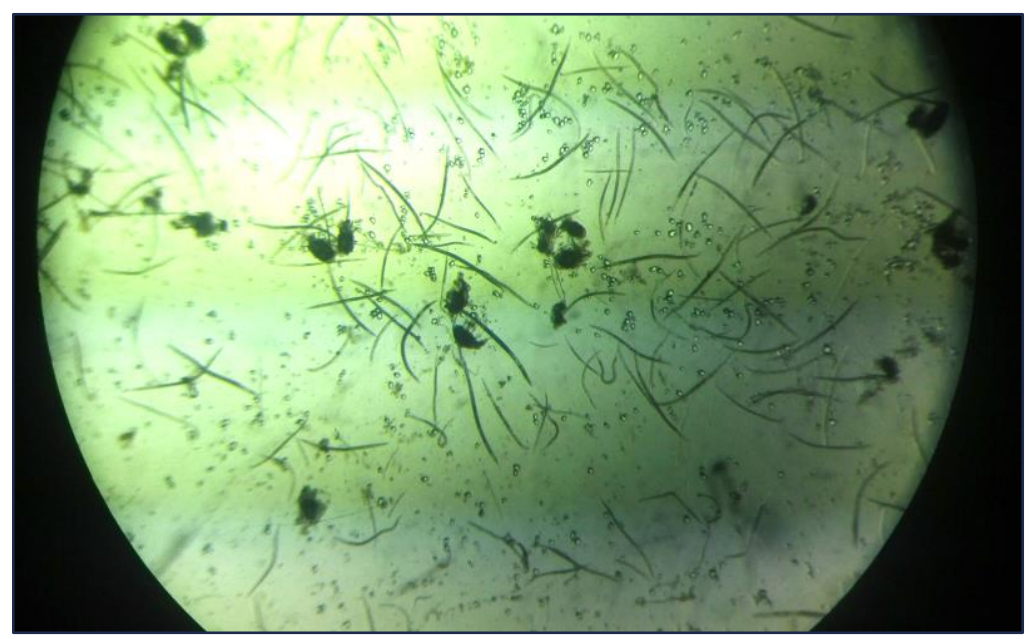

Figure 3. The nutritional process of mites with parasitic and saprophytic nematodes, which were extracted from infested potatoes by $D$. destructor, D. dipsaci, in advanced phases of ditylenchosis.

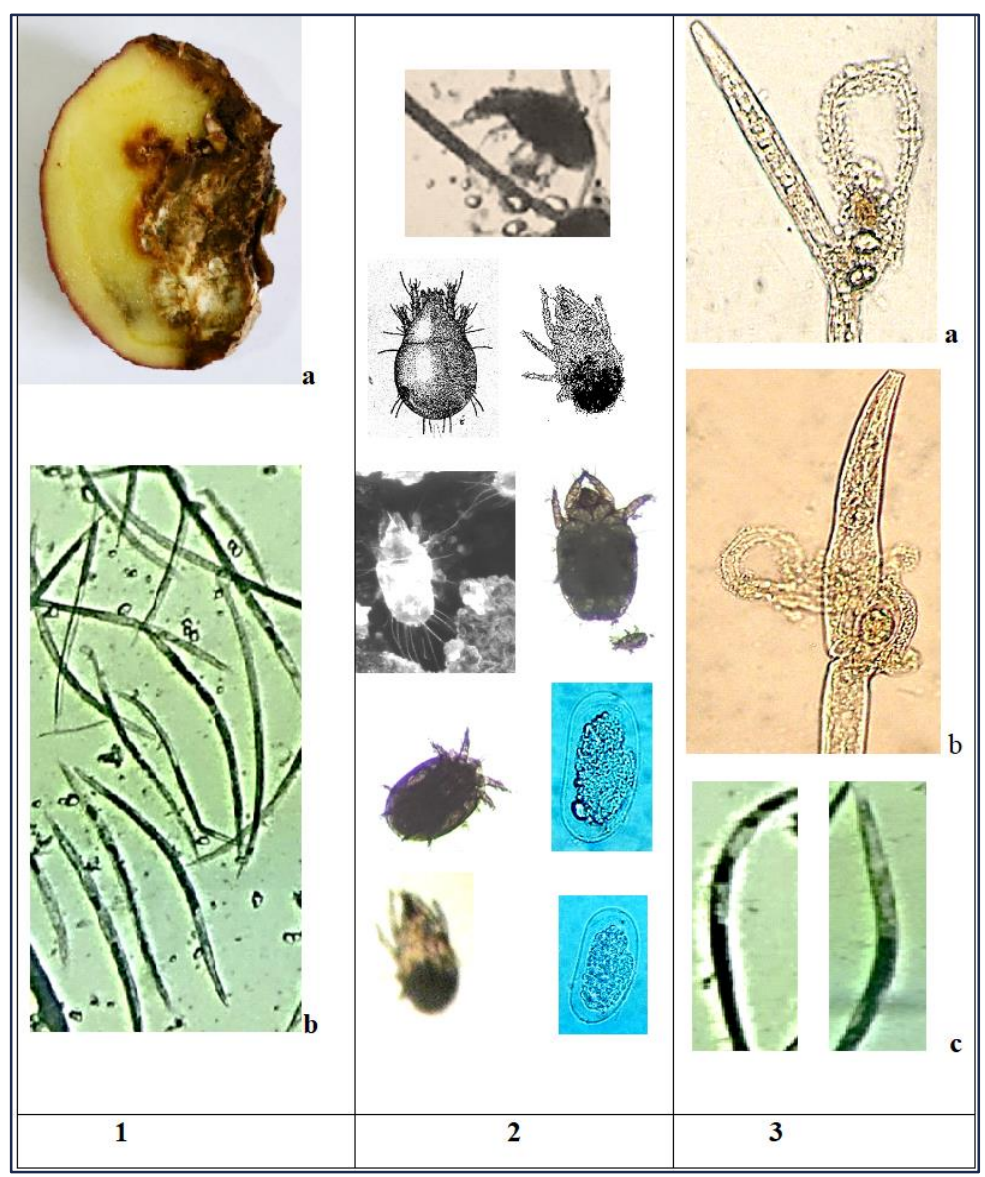

Figure 4. 1a - Potato tuber (section) infested by D. destructor in association with secondary parasites (saprophytic nematodes, microorganisms, nematophagous mites); $1 \mathrm{~b}$ - nematodes $D$. destructor, D. dipsaci, devoured by mites; 2 - species of nematophagous mites and their eggs; 3 - different species of dead nematodes after being in contact with mites (a, b - saprophytes; c - devoured portions of $D$. destructor). 
There have been observed cases, when in the infested potatoes, in which the density of mites accounted for hundreds of mature individuals/ tuber, all species of nematodes disappeared, as well as the bacterial and fungal infections. As a result, portions of the tuber with completely macerated substrate remained, containing only empty cells. Also, the starch granules disappeared in these phases of ditylenchosis. In such tubers, the passing from the infested to the non-infested portion and the extension of nematological, bacterial and fungal infections was not observed. Only a clear differentiation of not infested and infested portion of potatoes was observed, which demonstrates the cessation of parasitic, fungal and bacterial infection.

Mites were detected in the investigated potato tuber varieties (a significant number), which belong to the species of Rhyzoglyphus echinopus F. \& R., family Tyroglyphidae (fig. 4.2). It is a widespread phytophagous species, with a $0.4-0.5 \mathrm{~mm}$ body length.

Loads of eggs deposited by mites in the potatoes tubers was also observed. A female lays about 800 eggs on average. A generation might develop over

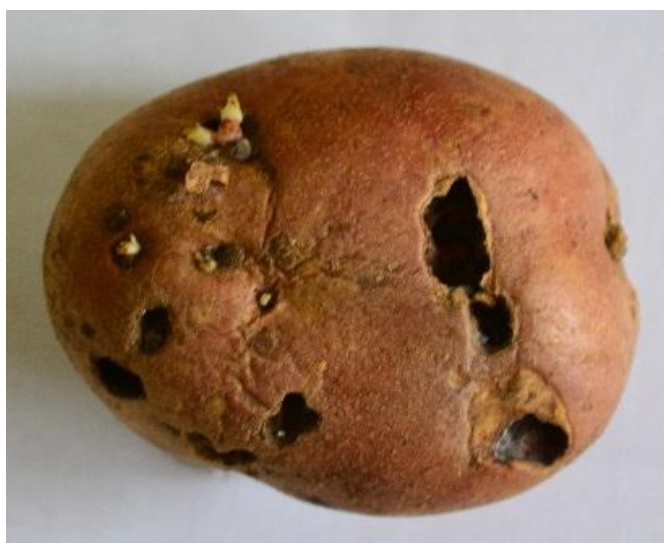

a

30 days. Their development occurs at a humidity of more than $60 \%$, being very sensitive to this factor. It should be mentioned, that the tubers contain an increased amount of water, depending on the potato variety (between $77 \%$ - variety Albastriu-mov and 83\% - Agata variety), but in the infested potatoes by primary parasites the amount of water increased with 5-6\%, creating favourable conditions for existence not only for mites, but also for bacteria, fungi and saprophytic nematodes.

\section{Phytophagous arthropods}

Wireworms of click beetles (family Elateridae). The research results showed that potato harvest at some of the analysed varieties (Agata, Bella rosa, Desiree, Roko, Sprinter, Concorde), originating from field culture, has been quite affected by some harmful phytophagous arthro-pods, such as wireworms of the click beetles (fig. 5b, 5c). Wireworms depreciate qualitatively the potato tubers due to the galleries, which are dug into the pulp. During the laboratory studies of the affected portions, it was observed that soil penetrated into those galleries (fig. 5a) made by the wireworms, thus favouring the colonization with bacterivore saprophytic nematode species.

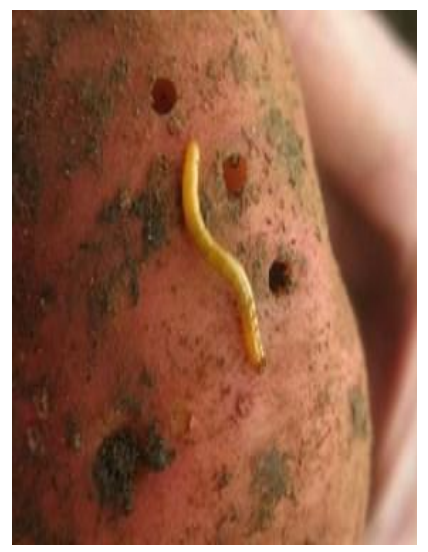

b

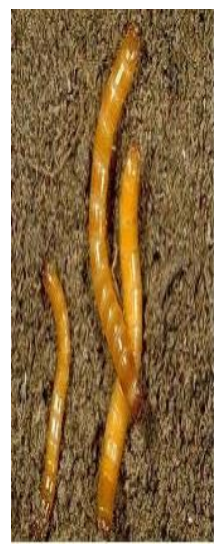

Figure 5. Potatoes attacked by wireworms of click beetles in association with saprophytic nematodes and mites $(\mathrm{a} ; \mathrm{b})(\mathrm{c}-$ wireworms, exterior aspect).

The laboratory investigation of the soil extracted from pulp galleries of the affected tubers demonstrated the presence of nematodes that eliminate bacterial and fungal infections of the order Rhabditida, families: Rhabditidae, Cephalobidae and order Dorylaimida, family Dorylaimidae (sp. Mesodorylaimus bastiani). In addition, crowds of mites were detected in the tested soil.

\section{Mole cricket (Gryllotalpa gryllotalpa L.)}

Among the phytophagous arthropods in some of the investigated varieties (Agata, Desiree, Irga, Roko, Iagodca), the presence of the common mole cricket (G. grillotalpa, family Grillotalpidae) has been established (fig. 6c). The observations made on individual lots in Roko potatoes variety determined $100 \%$ of mole cricket attack (fig. $6 a, 6 b$ ). Soil penetrates the mechanically traumatized 
tubers by mole cricket, in which the bacterial saprophytic nematodes were frequent found, which brought microorganisms on the body or intestine and cause both dry rot (Fusarium spp.) and wet rot (Erwinia spp.).

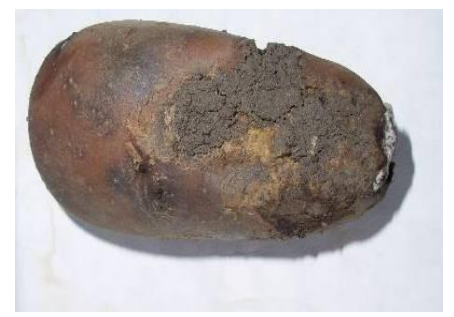

a

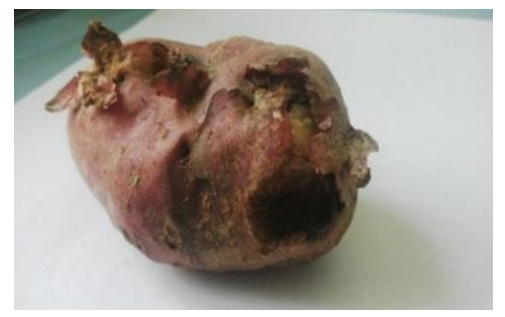

b

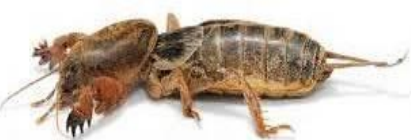

C

Figure 6. a, b - Potatoes tubers infested by D. destructor (phases 3, 4 of ditylenchosis) in association with secondary parasites and pests (with cavities formed by mole cricket); c - G. grillotalpa L. (exterior aspect).

Under laboratory conditions, most of the harvested tubers, affected by mole cricket bites, over a storage interval of 1.5-2.0 months at room temperature, turned into waste caused by the rot (fig. 7c). The insects produced huge cavities (fig. 7b) in the potato tubers, causing qualitative and quantitative deterioration of the potato crops, thus being transformed into waste.

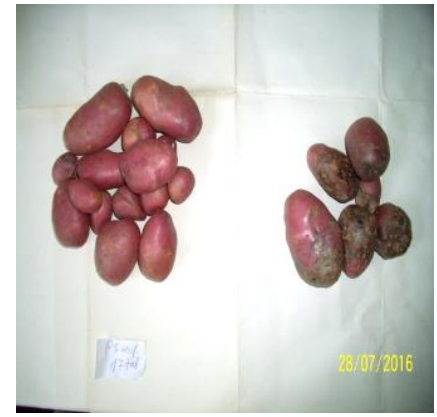

a

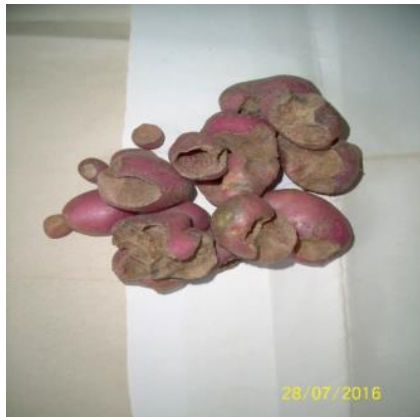

b

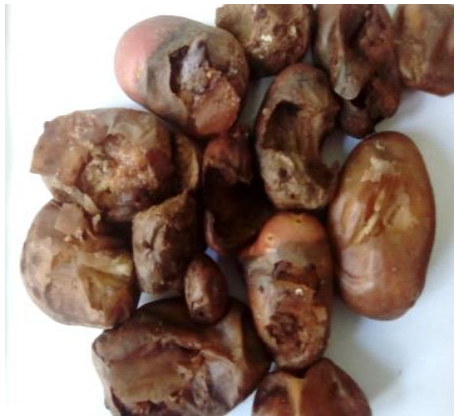

C

Figure 7. Roko variety potatoes (from field experiments, obtained from a mother tuber):

$\mathrm{a}$ - healthy potatoes; $\mathrm{b}$ - traumatized by mole cricket; $\mathrm{c}$ - traumatized by mole cricket after being kept in laboratory conditions for over 2-3 months at room temperature $-100 \%$ infestation of wet rot.

\section{Flies (Sciaridae spp.)}

In the researches carried out on 10 varieties of potatoes, flies were detected only in some of them such as Agata, Deziree, Iagodca, Roko, which were selected from the field crops, with primary and secondary parasites and some pests. The affected tubers are characterized by perforated surfaces, whereas the flies' larvae were frequently detected in the damaged tissue (fig. 8c). It has been determined that these belong to the Sciaridae family.

It was determined that the tubers associated with Sciaridae spp. occur in the advanced stages of ditylenchosis, phases 4-5, when these are in the process of decomposition. A series of parasites and pests might colonize such tubers, such as phytoparasitic nematodes, saprophytes, micro-organisms and mites. Sciaridae spp. usually lives in wet soil, attacks plant roots and feeds with their living tissue.

\section{DISCUSSIONS}

In the conditions of the Republic of Moldova, a wide spread (100\% frequency) of tubers obligatory primary parasite $-D$. destructor in all 10 researched varieties was observed. Resear-ches has shown an association of parasitic nematodes $D$. destructor and D. dipsaci (frequency $30 \%$ ) only in the varieties Albastrui-mov, Bella rosa, Desiree. In our opinion, this association displays a local character. Nematode $D$. destructor is frequently $(100 \%)$ accompanied by secondary parasitic nematodes (saprophytes), most being of the 


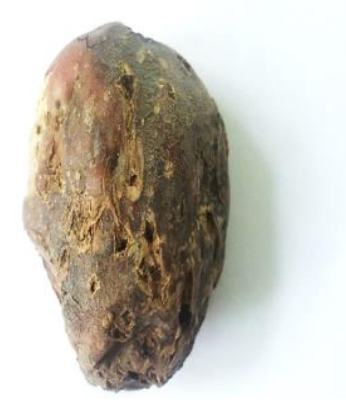

a

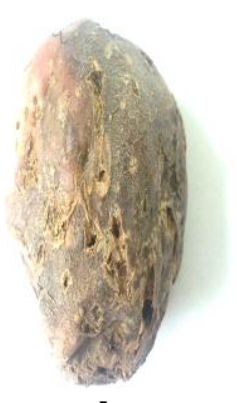

b

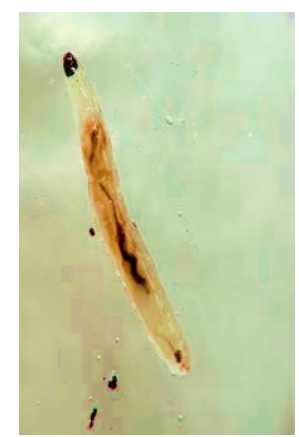

C

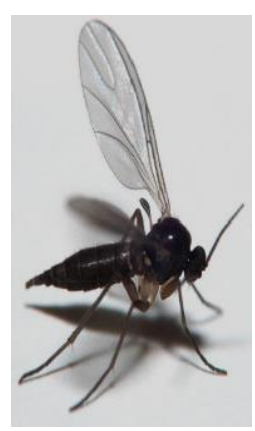

d

Figure 8. a - Roko variety potatoes infested by $D$. destructor in association with saprophytic nematodes, microorganisms, mites, flies; $b$ - holes in the pulp of the tuber through which Sciaridae spp. penetrated; c - larva; d - imago.

order Rabdithida. A frequent association (100\%) of the nematode $D$. destructor with dry rot caused by Fusarium spp. was determined. The wet rot $E r-$ winia spp was found less frequently (60\%) in the investigated varieties. It was observed that both primary parasitic nematodes and secondary saprophytic nematodes are not associated with wet rot and commonly leave the environment.

Our research reported an $80 \%$ frequency of mites, namely in the varieties of Agata, Albastriumov, Bella rosa, Concorde, Desiree, Irga, Iagodca, Roko. It has been determined that mites are common in tubercles infested with $D$. destructor in association with saprophytic nematodes and dry rot. Also, it was observed cases of active attack of mites on parasitic and saprophytic nematodes. Similar researches on nematode-mite interrelationships have been followed by other authors (8), who observed some processes regarding the perforation and nutrition of mites of the species Tyrophagus putrescentiae with the nematodes of the species Rhabditis spp., Cephalobus spp., Heterodera orizae. According to some researches (9) special importance is given to the mites of the genus Caloglyplus (Acarina: Acaridae), which shows a high efficacy in decreasing the density of parasitic nematodes. All stages of these mites attack the egg mass, laid by females, juvenile forms and females of the species Meloidogyne, Globodera rostochiensis and Heterodera schachtii, as well as endo- and ectoparasitic migratory species: Paratylenchus spp., Pratylenchus spp., Tylenchorhynchus spp. It has been established that the species Hypoaspis sculifer (family Gamasidae) attack the phytophagous nematode Tylenchorhynchus $d u-$ bius, reducing their populations up to $68 \%(10)$. The extensive researches of some authors $(11,12$,
13) determined that the mites of the species T. putrescentiae and Hypoaspis calcuttaensis are both nematophagous, consuming invasive larvae of the species Meloidogyne javanica and consumers of harmful fungi of plants: Fusarium, Alternaria, $\mathrm{Mu}$ cor etc. Researchers from Florida (Orlando) (14) observed that the mite Coleoscirus simplex (Ewing) (Cunaxidae: Coleoscirinae) colonizes greenhouse pot cultures of root knot nematodes (Meloidogyne spp.), where it preys on vermiform nematodes and soil arthropods. This is the first report of nematophagy in a cunaxid mite. Previous researches (15) have shown that potatoes tubers infested with $D$. destructor (phases 3-4-5 of ditylenchosis) are always colonized by various species of nematophagous mites from the family Acaridae, more common being individuals of the species Rhyzoglyphus echinopus. The phytophagous mite $R$. echinopus, also called bulb mite, infests both field plants and those stored in the warehouses $(10,14)$. They attack nematodes in the region of the gonad and oviduct with eggs that they consume actively, causing the mortality of both parasitic and saprophytic forms. Some species of mites (Gamasidae sp.) devour and use for food the parasitic species $D$. dipsaci and $D$. destructor, the daily norm being up to four small nematodes. At the same time, the presence of mites is important in regulating the density of nematodes under natural conditions (14). In our researches, all mite species present in potatoes tubers infested with nematodes and microorganisms proved to be active predators of phytophagous and saprophytic nematodes.

The harvested tubers are attacked by some phytophagous arthropods, such as wireworms of click beetles (fam. Elateridae), mole cricket 
(family Grillotalpidae) and flies (fam. Sciaridae).

The research results showed that $40 \%$ of the analysed varieties (Agata, Concorde, Roko, Sprinter) were attacked by the wireworms of click beetles. According to the experimental data of some authors (16), among the click beetles, the species of the genus Agriotes (family Elateridae) are widely spread in the Republic of Moldova. The presence of 6-8 wireworms per $1 \mathrm{~m}^{2}$ causes tuber damages up to $60 \%$, and the installation of various pathogens in the galleries left, favours the rot of tubers, leading to crop losses of up to $50 \%$ (17). In the process of laboratory investigations of the affected parts, it was observed that soil penetrates into the galleries through the pulp, which favours the colonization with bacterivore saprophytic nematode species of the order Rhabditida, these being active decimators of microbial infections. Similar results were obtained by other researchers (18), where potato tubers affected by wireworms are often subsequently infested by pathogenic bacteria and fungi, which cause dry and wet rot.

In monoculture conditions, the mole cricket (family Grillotalpidae) attack (frequency 50\%) was also observed namely on the varieties Albastruimov, Dessiree, Irga, Roko, Sprinter. It is a widespread polyphagous species in Europe, as well as in the Republic of Moldova, especially in conditions of increased humidity or on irrigated lots. In the superficial horizon of the soil $(0-20 \mathrm{~cm})$ a single female lays up to 500 eggs (19). Like the wireworm, the mole cricket cause tuber damage through mechanical damage, with the possibility of penetrating the soil with bacterivorous saprophytic nematodes, accompanied by various microorganisms, which stimulate the appearance of rot (Fusarium spp., Erwinia spp.) that over a period of storage turn the tubers into waste.

In the potato tubers, cultivated in monoculture condition, the presence of Sciaridae spp. (frequency $40 \%$ ) was detected in the varieties Agata, Deziree, Iagodca, Roko infested by the nematode D. destructor in combination with the saprophytic nematodes and microorganisms, in the 4-5 phases of ditylenchosis. These could be transmitters of both $D$. destructor nematodes (larvae, eggs) and various microbial infections. According to some researches (20), eggs and larvae of the nematode $D$. dipsaci were detected in the intestines of flies from the Drozophilidae family. According to the authors, the transmission of parasitic nematodes from one deposit to another might occur due to the flies.

\section{CONCLUSIONS}

1. Solanum tuberosum infested by Ditylenchus destructor in association with saprophytic nematodes and dry rot are colonized by nematophagous (frequency $80 \%$, different species of mites) and phytophagous arthropods (wireworms - 40\%; mole cricket - 50\%; flies - 40\%).

2. Potatoes tubers are preferred by different arthropods (Acaridae), Agriothes spp. (Elateridae), $G$. gryllotalpa (Grillotalpidae), Sciaridae spp. (Sciaridae), which form different interactions with the parasitic nematodes of tubers. Among the studied arthropods, Rhizoglyphus echinopus (Fumouze \& Robin, 1868) were more frequently found, which together with other species (Agriothes spp. (Elateridae), G. gryllotalpa (Grillotalpidae), Sciaridae spp. (Sciaridae)), actively consume the primary (D. destructor, D. dipsaci) and secondary parasitic nematodes (saprophytes, most being of the order Rhabditida), their mortality accounting for up to $90 \%$.

3. The Sciaridae spp. might carry the eggs of primary parasitic nematode species in potatoes from warehouses. Some phytophagous arthropods might damage potatoes, thus the secondary parasitic nematodes from the soil might penetrate and bring bacterial and fungal infections, subsequently stimulating the total rot of potatoes tubers.

\section{CONFLICT OF INTERESTS}

The author does not declare any conflict of interest.

\section{ACKNOWLEDGMENT}

The research was carried out within the project: 20.80009.7007.12 Diversity of hematophagous arthropods, zoo and phytohelminths, vulnerability, climate tolerance strategies and development of innovative procedures for integrated control of species of socio-economic interest. 


\section{REFERENCES}

1. Melnic M, Toderaș I, Erhan D, Rusu Ş, Onofraș L, Todiraș V. Methods for control and prophylaxis of parasitic nematodes in potatoes culture: Practical recommendations. Chișinău: I.E.P Știința, 2014.

2. Rojankovschi E, Ciurea A. Contribution of the study of interactions between the potato rot nematode (Ditylenchus destructor, Thorne) and fungi in the potato disease complex. Archiv fur. Phytopathologie und Phlanzenschutz.1986;22(2):101106.

3. Ivaniuc V.G, Iliasenco D.A. Stability of potatoes to stem nematoda (Ditylenchus destructor Thorne). Vesti nationalinoi Academii Nauk Belarus. 2010; 3:43-48.

4. Melnic M, Erhan D, Rusu S, Gherasim E, Chihai, N. Risk of use of seed potatoes infested with Ditylenchus destructor at initial phase of dityilenhosis. Materials of IX-th International conference of Zoologists ,Sustainable use, protection of animal world and forest management in the context of climate change. 2016;146-147.

5. Melnic M, Erhan D, Rusu Ş, Toderas I, Chihai N. Nematode of potatoes tubers, morphophysiological pathologies and bio-indicators of the phytosanitary state. Scientific bulletin. Journal of Ethnography, Natural Sciences and Museology. 2015; 22(35):35-44.

6. Nesterov PI. Phytoparasitic and free-living nematodes of the south-west of the USSR. Chișinău: Stiinta, 1979.

7. Seinhorst J.W.1962. On the kiling, fixation and transfering to glicerin of nematodes// Nematologica 8:29-3.

8. Bilgrami $\mathrm{AL}$, Tahseen $\mathrm{Q}, \mathrm{A}$. nematode feeding mite, Tyrophagus putrescentiae (Sarcoptiformis: Acaridae). Fundamental and Applied Nematology. 1992;5(15):477-478.

9. Sell P. Caloglyplus sp. (Acarina: Acaridae) an effective hematophagous mite on root-knot nematodes (Meloidogyne spp.). Nematologia. 1988;34: 246-248.

Date of receipt of the manuscript: 04/04/2021

Date of acceptance for publication: 16/06/2021

Maria MELNIC, ORCID ID: 0000-0002-5263-8845

Olesea GLIGA, ORCID ID: 0000-0002-4917-5106

Dumitru ERHAN, ORCID ID: 0000-0001-9722-4382

Stefan RUSU, ORCID ID: 0000-0002-3322-9173
10. Perju T, Oltean I, Timuș A. Mites and harmful nematodes of cultivated plants. Editura Poliam. ClujNapoca, 2001.

11. Pakyari H, Maghsoudlo M. Development and life table of Tyrophagus putrescentiae (Astigmata: Acaridae) on mushroom and phytonematode. Academic Journal of Entomology. 2011;4(2):59-63.

12. Swarz J, Catska V. Food selection of the field population of Tyrophagus putrescentiae (Schrank) (Acarida). Journal of Applied Entomology. 1987; 104:329-335.

13. Walia KK, Mathur S. Predatory behaviour of two nematophagous mites, Tyrophagus putrescentiae and Hypoaspis calcuttaensis on root-knot nematode. Meloidogyne javanica. Nematologia mediterranea. 1995;23:255-261.

14. Walter DE, Kaplan DT. Observations on Coleoscirus simplex (Acarina: Prostigmata), a predatory mite that colonizes greenhouse cultures of rootknot nematode (Meloidogyne spp.), and a review of feeding behavior in the Cunaxidae. Experimental and Applied Acarology. 1991; 12:47-59.

15. Melnic M, Erhan D, Rusu S. Nematophagous mites associated with potato tubers infested by nematodes Ditylenchus. International Symposium, Plant Protection - Results and Prospectives. 2015;81-84.

16. Filipov NA. Review of pests of gourds and potatoes in Moldova. Harmful entomofauna of vegetable crops in Moldova. Editura Stiinta. Kisinau, 1978:3-30.

17. Iliev $\mathrm{P}$, Botnari V. Production of early potato in the Republic of Moldova. Recommendations. Chisinau, 1999.

18. Belov GL, Zeyru VN, Vasilieva SV. Bacterial diseases of potato and methods for their diagnosis. Plant Protection and Quarantine. 2016;3:30-32.

19. Anisimov B.V, Belov GL, Varitsev YuA, et al. Protecting potatoes from diseases, pests and weeds. Potato grower. Moscow. 2009:272.

20. Gubina VG, Nematodes of plants and soil. Moscow: Nauka 1982:245. 